\title{
Study on the Impact of the Quality of Internal Control on the Performance of M\&A
}

\author{
Jianfei Leng, Pangjing Zhao
}

School of Business, Hohai University, Nanjing, China.

Email: 1jf200209@gmail.com,zpjingok@gmail.com

Received April 20 ${ }^{\text {th }}, 2013$; revised May 27 $7^{\text {th }}, 2013$; accepted July $3^{\text {rd }}, 2013$

Copyright (C) 2013 Jianfei Leng, Pangjing Zhao. This is an open access article distributed under the Creative Commons Attribution License, which permits unrestricted use, distribution, and reproduction in any medium, provided the original work is properly cited.

\begin{abstract}
In order to examine whether the internal control quality affects the M\&A performance (stock market return and accounting return) of acquiring firms after the Chinese SOX (Sarbanes-Oxley Act) issued, we select 126 mergers and acquisitions (M\&A) deals of Chinese non-financial listed companies on Shanghai and Shenzhen Stock Exchange in 2010 from the CSMAR (China Securities Market \& Accounting Research) Database. And we use content analysis to construct a score to quantify the internal control quality of Chinese listed companies. We examine the relationship between the quality of internal controls and the performance of bidding firms with event study and multivariate regression analysis. Our results indicate that the internal control quality of acquirers is positively related to the accounting rates of firms. The higher quality of internal control means that acquirers with better internal control system would be more likely to benefit from M\&A activities and create more value for the their own companies and shareholders. Another result is that investors on the stock market are more optimistic about M\&A activity lauched by firms which enjoy higher ICQS (the Internal Control Quality Score).
\end{abstract}

Keywords: Internal Control; Mergers and Acquisitions; Accounting Study; Event Study

\section{Introduction}

M\&A means that a company purchases all or part of another enterprise assets or equity to affect the control of the enterprise being acquired, to achieve its business objectives like entering new markets, increasing market share, or diversifying their operations. Prior research suggests that results from mergers and acquisitions (M\&A) are often disappointing compared with results predicted or expected. The majority of M\&A activities even caused decline to the bidding companies' performance. However, M\&A is still one of important means for enterprises to optimize the allocation of resources and expand into a new industry rapidly. M\&A have been occurring frequently in the market, some companies could benefit from M\&A. Over the years, domestic and foreign academics have done a lot of research on the performance of M\&A with different research methods and angles. Western literatures have obtained similar results that M\&A in general can make the target companies earn positively abnormal returns, but for the bidding companies, it is a little more difficult to benefit from mergers and acquisitions.
The entire M\&A process is a complicated project, including looking for the target company, the decision making, developing the program of acquisitions, due diligence, and integration phase after takeover completed. Each stage will affect the performance of deals. Whether the decision of M\&A is consistent with the long-term strategic objectives of the firm will play a key role on the performance of M\&A. Un-strategic M\&A tend to make the company fall into the plight of a long time. Rational decision-making and effective implementation of mergers and acquisitions will fundamentally guarantee the company to gain from mergers and acquisitions. The better internal control system tends to mean that firms enjoy stricter process of operational decision making.

After the promulgation of the US Sarbanes-Oxley Act in 2002, which is regarded as the most far-reaching reforms of American business practices since the time of Franklin Delano Roosevelt, China in May 2008 also enacted the Basic Norms for Enterprise Internal Control which is regarded as the Chinese Sarbanes-Oxley Act. The basic elements of Chinese internal control also include internal environment, risk assessment, control activities, information and communication, internal super- 
vision. After the Sarbanes-Oxley Act, to strengthen internal control is increasingly becoming an important method of many countries to improve the level of corporate governance to enhance the ability of risk prevention of firms. While simultaneously, in recent years, academic research on internal control is becoming more and more popular.

Internal control has a significant effect on solving agency problem, strategic decision making, strategic management and risk management which would affect performance of M\&A. Shleifer A. (1990) [1] found that managers' objectives driving M\&A which might made an impact on corporate performance. Thomas Straub (2007) [2] in his book-Reasons for Frequent Failure in Mergers and Acquisitions - promoted an understanding of factors underlying M\&A performance in business research and scholarship to help managers in the decision making process. PeiLing Wang (2007) [3] thought that agency problem was one of reasons of bad performance of postacquisitions among Chinese listed companies. Therefore, we assume that the quality of internal control would affect the performance of M\&A.

We begin our analysis by examining between internal control quality and M\&A performance. We use content analysis to measure the quality of internal control of acquirers. According to the COSO five elements of internal control, we calculate the Internal Control Quality Score (ICQS) to reflect the level of internal control based on the level of detail of relevant internal control information from public documents in 2010.

In May 2008, five departments such as China Securities Regulatory Commission and the Ministry of Finance jointly issued the Basic Norms for Enterprise Internal Control, which required listed companies to comply with since the July 1, 2009. On the other hand, in order to obtain the financial data in the event year and the first year after the M\&A, we select listed companies from the Shanghai Stock Exchange and Shenzhen Stock Exchange which completed M\&A activity in 2010. Then we use multiple regression to test the collected data to test the relationship between internal control and the performance of M\&A.

After empirical research with multiple linear regression model, we conclude that M\&A performance is positively associated with the quality of internal control. The acquirers with higher internal control quality will be more likely to effectively control the process of M\&A and to make M\&A activities become one of successful ways to achieve their long-term strategic objectives.

The remainder of this paper is organized as follow: Section 2 discusses prior research on the performance of M\&A and the effects of internal control. Section 3 put forward our hypotheses. Section 4 describes the method of the study. Section 5 presents empirical results. Section
6 draws some conclusions.

\section{Prior Research}

\subsection{Performance of M\&A}

M\&A activities originated in the late 19th century. After that there have been six massive waves of mergers and acquisitions so far. While simultaneously, the number of research on the performance of M\&A is also increasing.

Jensen, Ruback (1983) [4] investigates 13 successful mergers and acquisitions in the United States and found that targets would benefit $20 \%-30 \%$ abnormal returns from the M\&A cases, the acquirers, however, could gain only $4 \%$ of the equity premium. Gregg Jarrell and Annette Poulsen (1989) [5] analyze more than 450 successful M\&A deals between 1963 and 1986, discover that the average abnormal returns of targets could be more than $20 \%$, but the acquirers' return is not obvious, only $1.14 \%$. Healy P.M., Palepu K.G., Ruback R.S. (1992) [6] examine the post-acquisition performance for the 50 largest US mergers between 1979 and mid-1984 and they find that merged firms show significant improvements in asset productivity relative to their industries.

Hongqi Yuan (1998) [7] values the post-merger performance of acquiring firms by accounting rates return to empirically test the M\&A deals in 1997 and finds that the acquirers' earnings per share (EPS) and the rate of return (ROE) on common stockholders' equity are both improved, the liability ratio declines compared with last year. Genfu Feng, Linjiang Wu (2001) [8] and Hongli Wang (2005) [9] use accounting rates of return (like main business's increasing rate of income, the rate of return on total assets, etc.) to examine the performance of mergers and acquisitions. Their conclusions are similar that deals could not improve the acquirers consistently. The postmerger performance of acquirers will experience a process that increased first and then decrease. Xin Zhang (2003) [10] does empirical research on 1216 cases during 1993-2002 with both event study and accounting study. Their results suggest that the stock prices and financial performances of targets improve significantly after M\&A deals; but the reverse impact is seen on the bidding companies. Tao Zhu (2006) [11] investigates share price performance in the short and long run of M\&A and find that in the short term the share price of the acquiring firms will gain extraordinary returns, but in the long term the acquiring firms' shareholders will lose significantly. Xiaoping Liu, Xiaowei Huang, Hongyu Guo (2009) [12] use the theory of industry life cycle (ILC) and multivariate linear regression method to examine 749 M\&A samples chosen from Shanghai Stock Exchange and Shenzhen Stock Exchange with the sample period from 1998 to 2004. They find the performance of M\&A has something to do with ILC. 


\subsection{Effects of Internal Control}

In July 1978, a report of the Cohen Commission was to appeal the regulatory authorities to promote the enhancement of the supervision of the internal control. And in 1992 the Committee of Sponsoring Organizations of the Treadway Commission (COSO) developed the Internal Control-Integrated Framework to provide principlesbased guidance for designing and implementing effective internal controls. After the passage of the Sarbanes-Oxley Act in July 2002, COSO issued the Enterprise Risk Management-Integrated Framework in 2004 in response to a need for principles-based guidance. In 2009, COSO issued the Guidance on Monitoring Internal Control Systems designed to help organizations monitor the quality of their internal control systems. And there has been an increase in the number of studies on corporate internal control.

Ashbaugh-Skaife H., Collins D.W. (2008) [13] find that firms with internal control deficiencies have significantly higher idiosyncratic risk, systematic risk, and cost of equity. Doyle J.T., Ge W. (2007) [14] examine 705 firms that have disclosed at least one material weakness from August 2002 to November 2005 and find that the relation between weak internal controls and lower accruals quality is driven by weakness disclosures. Altamuro J., Beatty A. (2010) [15] examine the financial reporting effects of FDICIA internal control provisions. Their results suggest that internal control requirements increased loan-loss provision validity, earnings persistence and cash-flow predictability. Bargeron L.L., Lehn K.M., Zutter C.J. (2010) find that several provisions of SOX are likely to discourage risk-taking. Brochet (2010) [16] indicates that the SOX and regulatory actions may prompt the disclosures about insider transactions. Wanfu Li, Bin Lin and Lu Song (2011) [17] find that strengthening the construction of firms' internal control is an important way to promote the investment efficiency.

Some other literatures, however, show that the SOX sometimes has an negative effects on firms' performance. Patterson E.R., Smith J.R. (2007) [18] find that SarbanesOxley does not necessarily induce higher levels of control testing. The implementation of the internal control provisions increases the risk and cost of audit. Engel E., Hayes R.M., Wang X. (2007) [19] conclude that SOX has affected firms' going-private decisions and Zhang I.X. (2007) [20] finds that the mandate of an internal control test results in significant cost savings. Gao F., Wu J.S., Zimmerman J. (2009) [21] indicate that SOX results in the unintended consequences that small companies have incentives to stay small to be exempted from costly regulations.

\subsection{Comments on Prior Research}

We can summarize that foreign scholars have done re- search on M\&A very early and from different aspects. Their conclusion is that acquired firms could gain from M\&A in short term. But the results of the question that whether acquiring firms can benefit from M\&A are somewhat mixed. As for the studies on internal control, the majority of authors find that the SOX and a sound internal control system will play a positive role in enterprises operating activities though the implementation of the internal control provisions may increase the cost of audit. We can learn from the extant literature that the higher internal control quality will be more likely to improve the operating efficiency and effectively reduce the risk of investment.

\section{Hypothesis}

According to the foreign extant literature, there are two main factors leading to the poor performance of M\&A. One reason is that the motivation of $\mathrm{M} \& \mathrm{~A}$ is not strategic, and the other one is the risk of complex process of mergers and acquisitions. Amihud Y., Lev B. (1981) [22] indicate that managerial motive for conglomerate merger is to decrease their largely undiversifiable employment risk. Roll (1986) [23] argues that bidding firms may pay too much for their targets in the hubris context. Shleifer A., Vishny R.W. (1989) [24] find that managers can entrench themselves by making manager-specific investments that make it costly for shareholders to replace them. Morck R., Shleifer A., Vishny R.W. (1990) [25] conclude that managerial objectives may drive acquisitions that reduce bidding firms' value. Xin Zhang (2003) [10] indicates that the flawed decision-making mechanism (hubris hypothesis and agency motives) can explain why purchasing companies lose value in M\&A deals. Xingze Wu (2010) feels that the majority of Chinese M\&A activities are not driven by strategic objectives and short of rational planning process.

On the other hand, another factor impacting performance is the complexity of the M\&A process. Grubb T.M., Lamb R.B. (2001) [26] in their book indicate that the complexity leads 80 percent of mergers to fail. Gongrong Chen and Zhiqun Ai (2002) [27] believe that M\&A is a high-risk investment activity and the risk exists in the whole process. Zhaoyang $\mathrm{Xu}$ (2005) [28] analyzes the risk originated from the four steps of the M\&A process. Lei Chen (2007) [29] regards the whole process of M\&A as a very complex project, she states that the more complex the operation is, the greater need to strengthen internal control. Xuyong Xu (2009) [30] believes that currently Chinese bidding companies are short of the awareness of risk assessment and risk management mechanism in the M\&A process.

Too many factors should be considered before launching deals, for example, managers are supposed to check whether the objective of M\&A is consistent with the 
firms' long-term goals. Obviously, the higher internal control quality means that firms can alleviate the risk to some extent brought by hubris hypothesis and agency problem. Even, higher internal control quality means information about M\&A could be kept from insider trader to prevent stock price fluctuating sharply.Yongmei Cui, Xuan Yu (2011) [31] and Xiaoying Lu (2011) [32] indicate that internal control is an effective means of risk management. Therefore we assume that before and during the process of merger and acquisition, the risk assessment, systematic control activities and effective communication in firms could alleviate unnecessary losses, even improve the performance of M\&A.

Hypothesis 1: the long-term performance (accounting rates) is positively related to the internal control quality. This means that firms with higher quality of internal control could create more value for their shareholders in the long term through the M\&A activity.

Hypothesis 2: the short-term performance (CAR) is positively associated with the internal control quality. This means that acquirers with higher quality of internal control would gain more cumulative abnormal returns after announcements in the stock markets. Or in other words, stock investors prefer the acquisition activity launched by firms which own better internal control system.

\section{Research Design}

\subsection{Sample}

Our sample originate from the CSMAR (China Securities Market \& Accounting Research) Mergers \& Acquisitions Database including all nonfinancial Chinese listed firms (i.e., acquirers) on SZSE and SSE in the fiscal year of 2010 because we require financial reports to construct the Internal Control Quality Score (ICQS). We choose the year 2010 because prior that time Chinese listed firms were not subject to the additional reporting until Basic Norms for Enterprise Internal Control issued by five departments (i.e., China Securities Regulatory Commission and the Ministry of Finance and so on). The restriction results in an initial sample of 338 deals which are completed. Then we remove 212 observations lacking the data to conduct our empirical tests. Finally, 126 observations are used in our analysis.

The annual reports and data used in this paper are coming from CSMAR Mergers \& Acquisitions Database (www.gtarsc.com), website of SZSE (www.szse.cn) and website of SSE (www.sse.com.cn). We use SPSS 18.0 to analyze data.

\subsection{The Internal Control Quality Score (ICQS)}

According to the prior literature (Hongxing Fang (2011) [33]; Xiaoyin Lu (2011) [32]), we use content analysis based on the firms' financial reporting to develop a mea- sure of ICQS to test our hypothesis. We design an evaluation criterion (Table 1) to calculate the ICQS. And we define ICQS according to the equation: ICQS = ICQ/ TICQ. ICQ means scores of every item of internal control information disclosed in annual reports and TICQ means the maximum score $(\mathrm{TICQ}=12)$.

\subsection{The Performance of M\&A}

There is a rich literature on the performance of M\&A drawn on two principal sources of statistical evidence: stock market returns (event study) and accounting rates of return derived from firms' annual reports. The event study and accounting study are often used to measure the short-term and long-term performance of M\&A respectively. We intend to conduct our analysis with both methods.

\subsubsection{Accounting Study}

Xiao Chen and Xiaoyue Chen (1999) [34] through empirical study conclude that despite the accounting rates of return are often manipulated, the substantive impact of events will eventually be exposed in the accounting statements in the long-term. According to prior research ( $\mathrm{Pa}$ lepu (1986) [35], Xin Zhang (2003) [10]), we use ROE and EPS to measure the performance of M\&A.

In order to eliminate the effects of macroeconomic environment and industry changes as far as possible, we refer to the research method (Barber, Lyon (1996) [36])

Table 1. Evaluation criterion sheet.

\begin{tabular}{|c|c|c|}
\hline Items & Content & Scores \\
\hline Internal Environment & $\begin{array}{l}\text { Governance corporate } \\
\text { structure, human } \\
\text { resources politics, } \\
\text { corporate culture, } \\
\text { managerial } \\
\text { concepts, etc. }\end{array}$ & $\begin{array}{l}\text { Undisclosed }=0 ; \\
\text { Simply disclosed }=1 ; \\
\text { In detailed }=2\end{array}$ \\
\hline Risk Evaluation & $\begin{array}{l}\text { Identification of } \\
\text { internal and external } \\
\text { risks, risk analysis, } \\
\text { risk response, etc. }\end{array}$ & $\begin{array}{l}\text { Undisclosed }=0 ; \\
\text { Simply disclosed }=1 ; \\
\text { In detailed }=2\end{array}$ \\
\hline Control Activities & $\begin{array}{l}\text { Internal control } \\
\text { activities based on } \\
\text { risk evaluation }\end{array}$ & $\begin{array}{l}\text { Undisclosed }=0 \\
\text { Simply disclosed }=1\end{array}$ \\
\hline & & In detailed $=2$ \\
\hline $\begin{array}{l}\text { Information \& } \\
\text { Communication }\end{array}$ & $\begin{array}{l}\text { The establishment of } \\
\text { information and } \\
\text { communication system }\end{array}$ & $\begin{array}{l}\text { Undisclosed }=0 ; \\
\text { Simply disclosed }=1 ; \\
\text { In detailed }=2\end{array}$ \\
\hline Internal Supervision & $\begin{array}{l}\text { Internal supervision } \\
\text { from internal audit } \\
\text { department }\end{array}$ & $\begin{array}{l}\text { Undisclosed }=0 ; \\
\text { Simply disclosed }=1 ; \\
\text { In detailed }=2\end{array}$ \\
\hline $\begin{array}{l}\text { Verification Report } \\
\text { of Internal Control }\end{array}$ & $\begin{array}{l}\text { Verification report } \\
\text { from the outside } \\
\text { audit agency }\end{array}$ & $\begin{array}{l}\text { Undisclosed }=0 \\
\text { Otherwise }=2\end{array}$ \\
\hline
\end{tabular}


to provide a benchmark against which sample firms can be compared. The specific steps are as follows: 1) for each of firms in the samples we choose all other listed companies in the same industry as comparison group; 2) then we develop a control group matched sample firms to other similar-size firms on the basis of pre-event total assets $(25 \%-200 \%) ; 3)$ the third step of developing a control group that we consider matched sample firms to other firms with more similar pre-event performance, we regard the accounting rates (ROE) as the standard rate; 4) then the accounting rates of sample minus the accounting rates of control group respectively are the adjusted accounting rates to measure firms' performance.

There are some other factors that can impact on the performance of M\&A. Banz (1981) [37] finds that smaller-sized firms have had higher risk adjusted returns, on average, than larger firms. Ronggang Zhang (2006) [38] indicates that risk exists in the merging progress of financial leverage. Linghong Xie (2011) [39] concludes that the times of continuous M\&A may affect the performance of M\&A. Zhaohui $\mathrm{Hu}$ (2007) [40] discovers that the independent group has a positive impact on the performance of M\&A, but not significant statistically.

In order to control for other factors related to the performance of M\&A, we conduct a multivariate analysis by estimating the following logistic regression:

$$
\begin{aligned}
\mathrm{PE}= & \alpha_{0}+\alpha_{1} \mathrm{ICQS}+\alpha_{2} \mathrm{MSIZE}+\alpha_{3} \mathrm{LEV} \\
& +\alpha_{4} \mathrm{TIMES}+\alpha_{6} \mathrm{IND}+\varepsilon
\end{aligned}
$$

where PE is represented by adjusted ROE and adjusted EPS to indicate the performance of M\&A. The variable ICQS is the Internal Control Quality Score used to indicate the quality of internal control of acquirers. The size of M\&A (MSIZE) is computed as the ratio of the value of the transaction to the total assets prior to the deal. The second control is LEV means financial leverage measured at the fiscal year end prior to the year in which the deal is announced. The third, TIMES, is the times of all the M\&A deals during 2007-2009 three years. IND is the fourth control, measured as the number of directors in the firms' independent group.

\subsubsection{Event Study}

We use event study to assess the short-term impact of M\&A announcement on the value of a firm. The basic idea is to find the abnormal return which is the difference between the actual return of a security and the expected return. Then we sum all abnormal returns to calculate the Cumulative Abnormal Return (CAR) to investigate the stock market response to the firm's M\&A activity.

We use the market model to calculate the abnormal return and CAR. The market model is one of the benchmarks in measuring abnormal returns with daily data, with adjustments of daily closing prices for stock dividends and splits. (Wong A., Cheung K.Y. (2009)) [41] The market model which indicates a linear relationship between stock returns and returns on a market portfolio. We follow the methodology used by Xiaoping Liu (2009) [12] that a maximum of 271 daily return observations are used for the period around the event. The estimation period is $(-240,-41)$, and $(-30,30)$ is designated as the event period. The day $t=0$ is the announcement day.

Abnormal returns are computed as the difference between actual returns and estimated expected returns:

$$
R_{j t}^{\prime}=\alpha_{j}+\beta_{j} R_{m t}+\mu_{j t}
$$

$R_{j t}^{\prime}$ is the daily rate of return on security $j$ on day $t$ and $R_{m t}$ is the daily rate of return on market index on day t. $\alpha_{j}$ is a constant term, $\beta_{j}$ is a covariance between $R_{j t}^{\prime}$ and $R_{m t} \cdot \mu_{j t}$ is a model error term of security $j$ on day $t$. We use Equation (2) to calculate the $\alpha_{j}$ and $\beta_{j}$. The interval for the Equation (2) is $[-240$, $-41]$.

Abnormal returns are computed as the difference between actual returns and estimated expected returns:

$$
A R_{j t}=R_{j t}-\left(\alpha_{j}^{\prime}+\beta_{j}^{\prime} R_{m t}\right)
$$

The interval for the Equation (3) is $[-30,30] . R_{j t}$ is the daily rate of return on security $j$ over day $t . \alpha_{j}^{\prime}$ and $\beta_{j}^{\prime}$ are estimated parameters $\alpha_{j}$ and $\beta_{j} . A R_{j t}$ is the estimated abnormal return for security $j$ over day $t$.

$$
A A R_{t}=\frac{1}{N} \sum_{j=1}^{N} A R_{j t}
$$

We use Equation (4) to calculate the average abnormal return. $N$ is the number of firms with return data on day $t$.

In order to examine the cumulative effect of events, the cumulative average abnormal returns (CAR) are produced.

$$
\mathrm{CAR}_{t}=\sum_{t=-30}^{t} A A R_{t}=\frac{1}{N} \sum_{t=-30}^{t} \sum_{j=1}^{N} A R_{j t}
$$

Then, we could examine whether there is a significant difference between CAR and 0 . If the CAR is positive and statistically significant, then we could conclude that the firms' shareholders benefit from the events in the stock market in the short-term. If the CAR is negative and statistically significant, then we could conclude that events could cause losses to shareholders in short-term.

According to the mean of ICQS $(\mu)$ of the whole sample, we divide into two sub-sample. If $\mathrm{ICQI}_{j}>\mu$, then the firm $j$ would be regarded as a company enjoying a better internal control quality. If $\mathrm{ICQI}_{j}<\mu$, then the firm $j$ would be regarded as a company enjoying a worse internal control quality. 


\section{Empirical Results}

\subsection{Descriptive Statistics}

Table 2 displays the descriptive statistics for the variables used in the empirical tests. The minimum of ICQS is 0 , the maximum is 0.9167 , the mean is 0.4557 and the standard deviation 0.2370 , which means the internal control quality of Chinese listed firms vary a lot and the average level is not very high. The mean of ROE 0 , ROE 1 and EPS 1 are all less than 1, except that EPS 0, which suggests that acquiring firms could not benefit from M\&A. The minimum of MSIZE is 0.00008 and the maximum is 0.5534 , which shows that the scale of M\&A in china vary a lot. The mean of LEV shows that the level of financial leverage of Chinese acquirers is slightly high. The minimum of times of M\&A in recent three years is 0 , and the maximum is 12 , which indicates that most acquiring firms had merged or acquired before this time. The INDI shows that acquirers all own the independent director system.

\subsection{Accounting Rates of Return}

\subsubsection{Correlation Analysis}

We use Pearson correlation coefficient to test collinearity between variables. Collinearity doesn't exist if the correlation coefficient is less than 0.8 . The Table 3 provides the significant level and the correlations between variables. To facilitate discussion, we focus on the correlation coefficients. ICQS is significantly positively correlated with ROE 0, ROE 1, EPS 0 and EPS 1, and negatively related to MSIZE, LEV and INDI, but not significant statistically. LEV is positively related with ROE 1 , EPS 0 and EPS 1, but also not significant statistically. TIMES is negatively and significantly correlated with ROE 1 and EPS 1, which indicates that too many times of M\&A may lead to decline in firms performance. INDI is positively and significantly related with EPS 0 at the 0.1 confidence level. These statistics indicate that it is important to control for these characteristics when examing the relation between the acquirers' performance of M\&A and the internal control quality.

Table 2. Descriptive statistics.

\begin{tabular}{|c|c|c|c|c|}
\hline & Minimum & Maximum & Mean & Std. Deviation \\
\hline ICQS & 0 & 0.9167 & 0.4557 & 0.2370 \\
\hline ROE 0 & --0.9441 & 1.2063 & -0.00129 & 0.18595 \\
\hline ROE 1 & -0.4615 & 0.9133 & -0.00768 & 0.15325 \\
\hline EPS 0 & -1.6928 & 2.048 & 0.00836 & 0.41567 \\
\hline EPS 1 & -2.9055 & 1.289 & -0.0700 & 0.51666 \\
\hline MSIZE & 0.00008 & 0.5534 & 0.0503 & 0.092 \\
\hline LEV & 0.0645 & 0.871 & 0.517 & 0.1805 \\
\hline TIMES & 0 & 13 & 3.06 & 3.126 \\
\hline INDI & 2 & 9 & 4.21 & 1.366 \\
\hline Valid N & 126 & & & \\
\hline
\end{tabular}

ROE 0, ROE 1, EPS 0 and EPS 1 mean adjusted ROE and EPS. ROE 0 and EPS 0 selected from the financial statements of the event year. ROE 1 and EPS 1 selected from the financial statements after a year of events.

Table 3. Correlation between vectors of values (Pearson).

\begin{tabular}{ccccccccc}
\hline & ROE 0 & ROE 1 & EPS 0 & EPS 1 & ICQS & MSIZE & LEV & TIMES \\
\hline ICQS & $0.149^{*}$ & $0.208^{* *}$ & $0.198^{* *}$ & $0.243^{* * *}$ & 1 & & & \\
MSIZE & 0.047 & 0.066 & 0.027 & 0.064 & -0.038 & 1 & & \\
LEV & -0.024 & 0.036 & 0.098 & 0.039 & -0.022 & $-0.223^{*}$ & 1 & 1 \\
TIMES & -0.105 & $-0.185^{*}$ & -0.13 & $-0.221^{* *}$ & 0.142 & $-0.16^{*}$ & $0.210^{* *}$ & -0.046 \\
INDI & 0.071 & -0.116 & $0.174^{*}$ & -0.095 & -0.127 & $0.157^{*}$ & 0.011 & 1 \\
\hline
\end{tabular}

${ }^{* * *}$ Correlation is significant at the 0.01 level (2-tailed). ${ }^{* *}$ Correlation is significant at the 0.05 level (2-tailed). ${ }^{*}$ Correlation is significant at the 0.10 level (2-tailed). 


\subsubsection{Linear Regression Results}

Table 4 presents the results of linear regression that examines the relation between the internal control quality and the performance of M\&A (ROE 0, ROE 1, EPS 0 and EPS 1). The model 2, model 3 and model 4 are statistically significant (F-value $>3$ ). When adding control variables, in model 1 the ICQS is positively and significantly associated with ROE 0 at the $10 \%$ level, in model 2 is associated with ROE 1 at 5\% level, and in model 3, model 4 are related with EPS 0 and EPS 1 at $1 \%$ level respectively. The significant positive coefficients on ICQS in four models support our hypothesis that acquirers with higher quality of internal control are more likely to benefit from M\&A than others. In addition, we compared the coefficients of ICQS in four models and we found that the coefficient in model 2 is greater than that in model 1 , also coefficient in model 4 is greater than that in model 3 . We concluded that the impact on performance of M\&A in second year was greater than the event year, indicating that acquirers with higher quality of internal control are more likely to enjoy strategic motives to launch the M\&A.

\subsection{Stock Market Returns}

Table 5 displays the result of cumulative abnormal return analysis. In the event period $(-30,30)$, total sample obtains the CAR of $-1.81 \% . \quad \mathrm{ICQS}_{\mathrm{j}}>\mu$ is the mean of ICQS and ICQ is the ICQS of sample $j . \quad \operatorname{ICQS}_{\mathrm{j}}>\mu$ means firm $j$ enjoys higher quality of internal control. The CAR of these sample is $-0.53 \%$ for the period $(-30$, 30). On the contrary, the sample of $\operatorname{ICQS}_{\mathrm{j}}<\mu$ obtains the CAR of $-2.87 \%$. These CARs are all statistically significant at $1 \%$ level. We also analyzed abnormal returns during the pre-announcement period $(-30,-3)$, announcement period $(-2,2)$ and post-announcement period $(3,30)$ respectively.

Figure 1 shows the fluctuations of CAR of three kind of samples. The line of $\mathrm{ICQS}_{\mathrm{j}}>\mu$ fluctuates smoothly at the top. The line in the middle is the fluctuations of CAR of total sample. The bottom line increases firstly and reaches a peak during the announcement period, then decreased rapidly until the last. Investors would be more likely to take advantage of M\&A whose acquirers with lower internal control quality for speculation and lift share price, then sell stocks quickly after the event ends. Lower internal control quality means there are some defects existing in the management process. Insider trader is easier to get the message which is supposed to be secret. On the other hand, we concluded that the stock market is more optimistic about the performance of M\&A launched by firms with higher internal control quality.

Table 4. Regression results.

\begin{tabular}{ccccc}
\hline & Model 1 & Model 2 & Model 3 & Model 4 \\
\hline Variables & ROE 0 & ROE 1 & EPS 0 & EPS 1 \\
ICQS & $0.14^{*}(1.966)$ & $0.15^{* * *}(2.653)$ & $0.443^{* * *}(2.9)$ & $0.604^{* * *}(3.225)$ \\
MSIZE & $0.046(0.243)$ & $0.132(0.878)$ & $0.037(0.092)$ & $0.392(0.791)$ \\
LEV & $0.01(0.107)$ & $0.093(1.214)$ & $0.326(1.584)$ & $0.344(1.361)$ \\
TIMES & $-0.007(-1.342)$ & $-0.011^{* *}(-2.612)$ & $-0.025^{* *}(-2.084)$ & $-0.046^{* * *}(-3.173)$ \\
INDI & $0.012(0.93)$ & $-0.012(-1.26)$ & $0.059^{* *}(2.222)$ & $-0.032(-0.991)$ \\
Adj_R2 & 0.007 & 0.077 & 0.085 & 0.111 \\
F & 1.171 & $3.074^{* *}$ & $3.336^{* * *}$ & $4.114^{* * *}$ \\
\hline
\end{tabular}

Figures in brackets are t-value. ${ }^{* * *}$ Correlation is significant at the 0.01 level (2-tailed). ${ }^{* *}$ Correlation is significant at the 0.05 level (2-tailed). ${ }^{*}$ Correlation is significant at the 0.10 level (2-tailed).

Table 5. Cumulative abnormal return analysis.

\begin{tabular}{|c|c|c|c|c|c|c|}
\hline \multirow[b]{2}{*}{ Event period } & \multicolumn{2}{|c|}{ Total sample $(\mathrm{n}=126)$} & \multicolumn{2}{|c|}{$\mathrm{ICQS}_{\mathrm{j}}<\mu \quad(\mathrm{n}=57)$} & \multicolumn{2}{|c|}{$\mathrm{ICQS}_{\mathrm{j}}<\mu \quad(\mathrm{n}=69)$} \\
\hline & $\mathrm{CAR} \%$ & T-value & $\mathrm{CAR} \%$ & T-value & CAR\% & T-value \\
\hline$(-30,30)$ & -1.81 & $-18.53^{* * *}$ & -0.53 & $-8.55^{* * *}$ & -2.87 & $-19.09^{* * *}$ \\
\hline$(-30,-3)$ & -1.41 & $-11.87^{* * *}$ & -0.31 & $-3.98^{* * *}$ & -2.31 & $-12.1^{* * *}$ \\
\hline$(-2,2)$ & -1.03 & $-13.84^{* * *}$ & -0.4 & $-7.98^{* * *}$ & -1.56 & $-9.89^{* * *}$ \\
\hline$(3,30)$ & -2.34 & $-21.90^{* * *}$ & -0.77 & $-8.40^{* * *}$ & -3.65 & $-22.26^{* * *}$ \\
\hline
\end{tabular}

\footnotetext{
${ }^{* * *}$ Correlation is significant at the 0.01 level (2-tailed).
} 


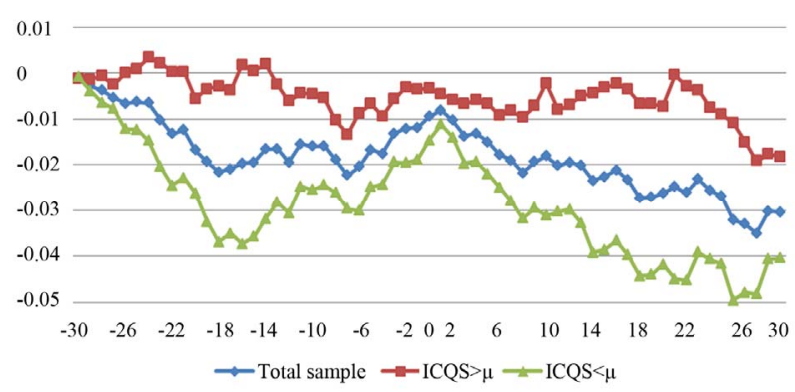

Figure 1. CAR comparison.

\section{Conclusions}

Our study provides evidence that acquirers with higher quality of internal control would be more likely to benefit from M\&A activities and create more value for the companies and its shareholders. First, we document that prior research on performance of M\&A and the effects of internal control. Second, we elaborate the possible impact of internal control on the performance of M\&A and then we put forward our hypotheses. Third, we do research on 126 Chinese listed acquirers with accounting study and event study. Specifically, the result of accounting study indicates that the internal control quality is positively and significantly associated with accounting rates. The result of event study shows that the internal control quality also exist positive impact on acquirers' share price.

Acquirers enjoying higher quality of internal control often means they operate with a healthy and systematic mechanism. Firms with better corporate culture, human resources, risk management, supervisory mechanism and communication are more likely to succeed in many ways including M\&A activities. On the other hand, we conclude that the stock market is more optimistic about the performance of M\&A launched by firms with higher internal control quality. These firms often give top priority to the interests of the company and the shareholders. Future research can explore how the quality of internal control affects the performance of different kinds of M\&A.

\section{REFERENCES}

[1] R. Morck, A. Shleifer and R. W. Vishny, "Do Managerial Objectives Drive Bad Acquisitions?" Journal of Finance, Vol. 45, No. 1, 1990, pp. 31-48. doi:10.1111/j.1540-6261.1990.tb05079.x

[2] T. Straub and J. C. Jarillo, "Reasons for Frequent Failure in Mergers and Acquisitions: A Comprehensive Analysis," Deutscher Universitäts-Verlag, Wiesbaden, 2007. doi:10.1007/978-3-8350-9637-0

[3] P. L. Wang, Y. H. Jin and J. J. Chang, "Analysis of M \& A Activities on the Agency Costs of Listed Company in China," Journal of Financial Research, No. 4, 2007, pp. 171-177.

[4] M. C. Jensen and R. S. Ruback, "The Market for Corpo- rate Control: The Scientific Evidence," Journal of Financial Economics, Vol. 11, No. 1, 1983, pp. 5-50. doi:10.1016/0304-405X(83)90004-1

[5] G. A. Jarrell and A. B. Poulsen, "The Returns to Acquiring Firms in Tender Offers: Evidence from Three Decades," Financial Management, Vol. 18, 1989, pp. 12-19. doi: $10.2307 / 3665645$

[6] P. M. Healy, K. G. Palepu and R. S. Ruback, "Does Corporate Performance Improve after Mergers?" Journal of Financial Economics, Vol. 31, No. 2, 1992, pp. 135-175. doi:10.1016/0304-405X(92)90002-F

[7] H. Q. Yuan, "Empirical Analysis of the Assets Reorganization of Listed Companies," Economic Management, Vol. 3, 1998, p. 024.

[8] G. F. Feng and L. J. Wu, "An Empirical Study of the M \& A Performance of Chinese Listed Companies," Economic Research Journal, No. 1, 2001, pp. 54-61.

[9] H. L. Wang, "Discussion on the Classification of the Research Methods of M \& A Performance," Modern Economic Science, No. 1, 2005, pp. 70-75.

[10] X. Zhang, "Do Mergers and Acquisitions Create Value: Evidence from Chinese Listed Companies," Economic Research Journal, No. 6, 2003, pp. 20-29.

[11] T. Zhu, "Toward the Short and Long Run Share Price Performance of M \& A for China Listed Companies," Modern Economic Science, No. 3, 2006, pp. 31-39.

[12] X. P. Liu, X. W. Huang and H. Y. Guo, "The Empirical Study of Industry Life Cycle, the Types of M \& A and the Performance of M \& A," Journal of Financial Research, No. 3, 2009, pp. 135-153.

[13] H. Ashbaugh-Skaife, D. W. Collins and R. Lafond, "The Effect of Sox Internal Control Deficiencies on Firm Risk and Cost of Equity," Journal of Accounting Research, Vol. 47, No. 1, 2008, pp. 1-43. doi:10.1111/j.1475-679X.2008.00315.x

[14] J. T. Doyle, W. Ge and S. McVay, "Accruals Quality and Internal Control over Financial Reporting," The Accounting Review, Vol. 82, No. 5, 2007, pp. 1141-1170. doi:10.2308/accr.2007.82.5.1141

[15] J. Altamuro and A. Beatty, "How Does Internal Control Regulation Affect Financial Reporting?" Journal of Accounting and Economics, Vol. 49, No. 1, 2010, pp. 58-74. doi:10.1016/j.jacceco.2009.07.002

[16] F. Brochet, "Information Content of Insider Trades before and after the Sarbanes-Oxley Act," The Accounting Review, Vol. 85, No. 2, 2010, pp. 419-446. doi:10.2308/accr.2010.85.2.419

[17] W. F. Li, B. Lin and L. Song, "The Role Played by the Internal Control in Companies' Investment: Is It a Promotion of Efficiency or a Repression Thereof?" Management World, No. 2, 2011, pp. 81-99.

[18] E. R. Patterson and J. R. Smith, "The Effects of SarbanesOxley on Auditing and Internal Control Strength," The Accounting Review, Vol. 82, No. 2, 2007, pp. 427-455. doi:10.2308/accr.2007.82.2.427

[19] E. Engel, R. M. Hayes and X. Wang, "The SarbanesOxley Act and Firms' Going-Private Decisions," Journal 
of Accounting and Economics, Vol. 44, No. 1, 2007, pp. 116-145. doi:10.1016/i.jacceco.2006.07.002

[20] I. X. Zhang, "Economic Consequences of the SarbanesOxley Act of 2002," Journal of Accounting and Economics, Vol. 44, No. 1, 2007, pp. 74-115. doi:10.1016/j.jacceco.2007.02.002

[21] F. Gao, J. S. Wu and J. Zimmerman, "Unintended Consequences of Granting Small Firms Exemptions from Securities Regulation: Evidence from the Sarbanes-Oxley Act," Journal of Accounting Research, Vol. 47, No. 2, 2009, pp. 459-506. doi:10.1111/j.1475-679X.2009.00319.x

[22] Y. Amihud and B. Lev, "Risk Reduction as a Managerial Motive for Conglomerate Mergers," The Bell Journal of Economics, Vol. 12, No. 2, 1981, pp. 605-617. doi: $10.2307 / 3003575$

[23] R. Roll, "The Hubris Hypothesis of Corporate Takeovers," Journal of Business, Vol. 9, No. 2, 1986, pp. 197-216. doi:10.1086/296325

[24] A. Shleifer and R. W. Vishny, "Management Entrenchment: The Case of Manager-Specific Investments," Journal of Financial Economics, Vol. 25, No. 1, 1989, pp. 123-139. doi:10.1016/0304-405X(89)90099-8

[25] R. Morck, A. Shleifer and R. W. Vishny, "Do Managerial objectives Drive Bad Acquisitions?" Journal of Finance, Vol. 45, No. 1, 1990, pp. 31-48. doi:10.1111/j.1540-6261.1990.tb05079.x

[26] T. M. Grubb and R. B. Lamb, "Capitalize on Merger Chaos: SIX Ways to Profit from Your Competitors' Consolidation and Your Own," Free Press, 2001.

[27] G. R. Chen and Z. Q. Ai, "Disscusion on the Financial Risk of M \& A," Enterprise Vitality, No. 2, 2002, pp. 69-71.

[28] Z. Y. Xu, "Systematic Features and Construction of Business M \& A Risk Management Procedure," Commercial Research, No. 10, 2005, pp. 70-73.

[29] L. Chen, "Analysis of the Internal Control of Mergers and Acquisitions," Agricultural Economy, No. 7, 2007, pp. 78-79.

[30] X. Y. Xu, "The Research on M \& A Value and Internal Control of Mergers and Acquisitions," Beijing Jiaotong University, Beijing, 2009.

[31] Y. M. Cui and X. Yu, "Study on the Evaluation of Inter- nal Control Based on the Process of Strategic M \& A," Accounting Research, No. 6, 2011, pp. 57-62.

[32] X. Y. Lu, "A Study on the Impact of Internal Control to the Performance of Mergers and Acquisitions of Listed Company," Tianjin University, Tianjin, 2011.

[33] H. X. Fang and Y. N. Jin, "Can High Quality Internal Control Reduce Earnings Management? An Empirical Research Based on Voluntary Internal Control Audits Reporting," Accounting Research, No. 8, 2011, pp. 53-60.

[34] X. Chen, X. Y. Chen and Z. Liu, "Research on the Usefulness of Earning Reports-Evidence from Shanghai and Shenzhen Stock Markets," Economic Research Journal, Vol. 6, 1999, pp. 21-28.

[35] K. G. Palepu, "Predicting Takeover Targets: A Methodological and Empirical Analysis," Journal of Accounting and Economics, Vol. 8, No. 1, 1986, pp. 3-35. doi:10.1016/0165-4101(86)90008-X

[36] B. M. Barber and J. D. Lyon, "Detecting Abnormal Operating Performance: The Empirical Power and Specification of Test Statistics," Journal of financial Economics, Vol. 41, No. 3, 1996, pp. 359-399. doi:10.1016/0304-405X(96)84701-5

[37] R. W. Banz, "The Relationship between Return and Market Value of Common Stocks," Journal of Financial Economics, Vol. 9, No. 1, 1981, pp. 3-18. doi:10.1016/0304-405X(81)90018-0

[38] R. G. Zhang and R. R. Zhang, "Application of Financial Leverage in Enterprises M \& A and Risks," Journal of Chang'an University (Social Science Edition), Vol. 8, No. 2, 2006.

[39] L. H. Xie, S. C. Liu and Y. H. Qiu, "Impact of Learning Managers' Over-Confidence in Serial M \& A Performances-Data from China's Listed Companies," Management Review, Vol. 23, No. 7, 2011, pp. 149-154.

[40] Z. H. Hu and Y. Xia, "Can Independent Directors Increase the Bidding-Firm Shareholders' Wealth-Data from of the Takeover Evidence China's Listed Companies," Journal of Shanxi Finance and Economics University, No. 4, 2007, pp. 78-84.

[41] A. Wong and K. Y. Cheung, "The Effects of Merger and Acquisition Announcements on the Security Prices of Bidding Firms and Target firms in Asia," International Journal of Economics and Finance, Vol. 1, No. 2, 2009, p. 274. 